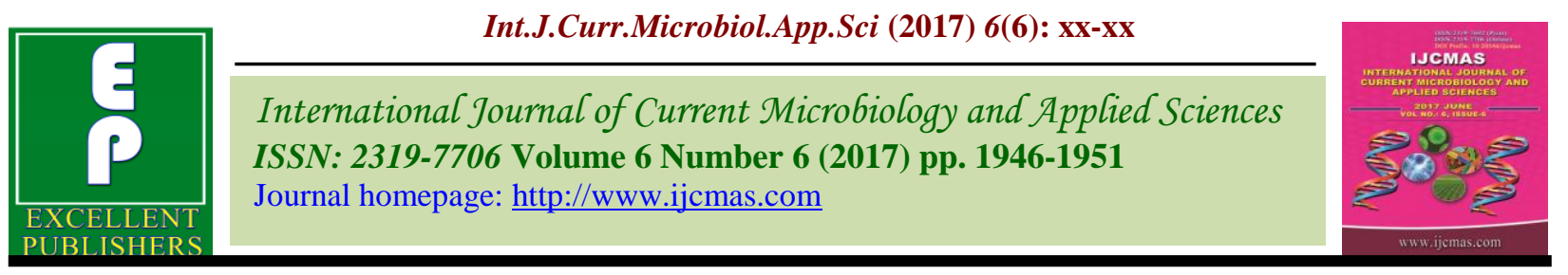

Original Research Article

https://doi.org/10.20546/ijcmas.2017.606.227

\title{
Effect of Different Planting Pattern and Nitrogen Management in Pearlmillet (Pennisetum glaucum L.) + Greengram (Vigna radiata L.) Intercropping System
}

\section{Virpal Kaur and Rajesh Singh*}

\author{
Department of Agronomy, SHIATS, Allahabad, 211007 (U.P), India \\ *Corresponding author:
}

\begin{tabular}{|c|c|}
\hline & A B S T R A C T \\
\hline $\begin{array}{l}\text { Ke y w or d s } \\
\text { Pearlmillet, } \\
\text { Nitrogen } \\
\text { management, } \\
\text { Planting patterns, } \\
\text { Azotobacter, } \\
\text { Azospirillum. }\end{array}$ & \multirow{3}{*}{$\begin{array}{l}\text { A field experiment was conducted during the kharif season } 2015 \text { at the Crop } \\
\text { Research Farm Department of Agronomy, Allahabad School of Agriculture, } \\
\text { SHIATS, Allahabad (U.P.) to study the effect of planting patterns and nitrogen } \\
\text { management in Pearlmillet (Pennisetum glaucum L.) and greengram (Vigna } \\
\text { radiata L.) intercropping system laid out in Randomized Block Design with } \\
\text { fifteen treatments replicated thrice. The results revealed that paired row system }+ \\
50 \% \text { RDN to Pearlmillet }+ \text { Azospirillum }+ \text { Azotobacter (Seed inoculation) } \\
\text { produced significantly higher plant height }(250.03 \mathrm{~cm}) \text {, dry weight }(103.33 \mathrm{~g}) \text {, no. } \\
\text { of tillers plant }{ }^{-1} \text { (2.67), test weight }(8.10) \text { and grain yield }\left(2.96 \mathrm{t} \mathrm{ha}^{-1}\right) \text { of } \\
\text { Pearlmillet along with comparable yield of greengram and also the highest benefit } \\
\text { cost ratio (1.73). }\end{array}$} \\
\hline Article Info & \\
\hline $\begin{array}{l}\text { Accepted: } \\
\text { 23 May } 2017 \\
\text { Available Online: } \\
\text { 10 June } 2017\end{array}$ & \\
\hline
\end{tabular}

\section{Introduction}

Pearlmillet is a short duration crop well adapted to less and erratic rainfall conditions. It is grown on large scale due to its drought escaping mechanisms and lower water requirement as compared to other cereals like sorghum and Maize. Application of inorganic fertilizers, no doubt has increased production but is becoming costlier day by day. Hence nutrient supply system involving biofertilizers in conjunction with chemical fertilizers is necessary to meet the crop nutrient demand (Meena and Gautam, 2005)

Application of nitrogenous fertilizer has played a key role in increasing food grains production in the country and will continue to do so in future. Bio-fertilizers play an important role in increasing availability of nutrients as well as enhancing productivity in a sustainable manner. Azotobacter and Azospirillum are free living bacteria for $\mathrm{N}$ fixation in soils.

On an average, the former can fix $20-40 \mathrm{~kg}$ $\mathrm{N} / \mathrm{ha}$, whereas, the later can fix $20 \mathrm{~kg} \mathrm{~N}^{-1}$ year ${ }^{-1}$ besides promoting a release of growth promoting substances (Singh et al., 2013). Soil microbes play an important role in many critical ecosystem processes, including nutrient cycling and homeostasis, 
decomposition of organic matter, as well as promoting plant health and growth as biofertilization (Han et al., 2007).

The arable land is a precious and scarce resource so, among the options to increase production, the cropping intensity and efficient utilization of available resources seems more feasible over increasing area under cultivation. But, under rainfed conditions only one growing season is available for cropping, so the farmers simultaneously have to raise two or more crops on the same piece of land to derive maximum output per unit of land through intercropping system. Sowing of Pearlmillet in paired row system has been proved advantageous over uniform row system, as it widens the scope of introducing a legume as an intercrop without having any adverse effect on the productivity of the base crop (Ram et al., 2005). Therefore the present experiment was conducted at crop Research Farm, SHIATS to find out the effect of levels of nitrogen along with biofertilizer seed inoculation and row spacing of Pearlmillet on growth, yield and economics of Pearlmillet + Greengram Intercropping System.

\section{Materials and Methods}

The experiment was carried out during Kharif season 2015 at Crop Research Farm, Department of Agronomy, Allahabad School of Agriculture, Sam Higginbottom Institute of Agriculture, Technology and Sciences, Allahabad (U.P.), which is located at $25^{\circ} 24^{\prime}$ $42^{\prime \prime} \mathrm{N}$ latitude, $81^{0} 50$ ' 56" E longitude and 98 $\mathrm{m}$ altitude above the mean sea level.

The experimental soil was sandy loam in texture with $\mathrm{pH} 7.34$, EC $0.27 \mathrm{dS} \mathrm{m} \mathrm{m}^{-1}$, available N $190.3 \mathrm{~kg} / \mathrm{ha}$, available Phosphorus $22.5 \mathrm{~kg} / \mathrm{ha}$ and available $\mathrm{K} 187 \mathrm{~kg} / \mathrm{ha}$. The experiment was laid out in a Randomized Block Design with 15 treatments replicated thrice, comprising 2 planting patterns URS, uniform row system at $60 \mathrm{~cm}$ and PRS, paired row system at $90 / 30 \mathrm{~cm}$ and 5 nitrogen management practices [RDN (Recommended dose of Nitrogen), 50\% RDN, 50\% RDN + Azospirillum (seed inoculation), 50\% RDN + Azotobacter (seed inoculation), 50\% RDN + Azospirillum + Azotobacter (seed inoculation)]. Inoculation of seed with biofertilizers was done just before sowing the seed. The plot size for each treatment was $12 \mathrm{~m}^{2}$. The recommended seed rates of $5 \mathrm{~kg} / \mathrm{ha}$ and $20 \mathrm{~kg} / \mathrm{ha}$ of Pearlmillet and greengram respectively used in the experiment. Pearlmillet variety 'Narmada-6022' and greengram 'PDM -139'were sown on 29 july 2015 and harvested on 9th October, 2015. The recommended dose of 100:50:40 kg NPK ha ${ }^{1}$ was applied to Pearlmillet. Nitrogen was applied in three split doses, full dose of phosphorus and potash was applied at the time of sowing.

\section{Results and Discussion}

\section{Growth, yield attributes and yield of pearlmillet}

Plant height and dry weight showed a significant increase due to various treatments Maximum plant height $(250.03 \mathrm{~cm})$ and dry weight $(103.33 \mathrm{~g})$ was recorded with $50 \%$ RDN+ Azospirillum + Azotobacter (seed inoculation) in intercropping with paired row planting pattern. Similar results have been reported by Muraleedharan et al., (2010). Biofertilizers are known to promote growth by increasing the availability of primary nutrients and/or growth stimulus to the target crop when applied to seed, plant surfaces, or soil (Alagawadi and Gaur, 1992). Significantly higher spike length $(28.97 \mathrm{~cm})$, grain yield $\left(2.96 \mathrm{t} \mathrm{ha}^{-1}\right)$ and test Weight $(8.10$ g) was obtained in P.R. (Pearlmillet + Greengram) $+50 \%$ RDN+ Azospirillum + Azotobacter (seed inoculation) (Table 1). 
Table.1 Effect of different planting pattern and nitrogen management on growth, yield attributes and yield of pearlmillet

\begin{tabular}{|c|c|c|c|c|c|}
\hline Treatment & $\begin{array}{c}\text { Plant } \\
\text { Height } \\
\text { (cm) }\end{array}$ & $\begin{array}{c}\text { Dry } \\
\text { Weight } \\
\text { (g) }\end{array}$ & $\begin{array}{c}\text { Spike } \\
\text { length } \\
(\mathrm{cm}) \\
\end{array}$ & $\begin{array}{c}\text { Grain } \\
\text { yield } \\
\left(\mathrm{t} \mathrm{ha}^{-1}\right) \\
\end{array}$ & $\begin{array}{c}\text { Test weight } \\
\text { (g) }\end{array}$ \\
\hline U.R.( Pearlmillet + Greengram) + RDN & 235.90 & 101.63 & 28.93 & 2.15 & 7.35 \\
\hline U.R. ( Pearlmillet + Greengram $)+50 \%$ RDN & 206.67 & 97.92 & 24.73 & 1.98 & 6.19 \\
\hline U.R.( Pearlmillet + Greengram $)+50 \%$ RDN + Azospirillum & 230.20 & 99.63 & 27.47 & 2.00 & 7.79 \\
\hline U.R. $($ Pearlmillet + Greengram $)+50 \%$ RDN + Azotobacter & 230.60 & 100.78 & 27.07 & 2.12 & 7.40 \\
\hline $\begin{array}{l}\text { U.R. }(\text { Pearlmillet }+ \text { Greengram })+50 \% \text { RDN }+ \text { Azospirillum }+ \\
\text { Azotobacter }\end{array}$ & 233.27 & 101.33 & 28.63 & 1.92 & 7.28 \\
\hline P.R.( Pearlmillet + Greengram) + RDN & 239.90 & 102.03 & 28.73 & 2.25 & 7.44 \\
\hline P.R. ( Pearlmillet + Greengram $)+50 \%$ RDN & 227.27 & 99.87 & 25.07 & 1.90 & 6.30 \\
\hline P.R. $($ Pearlmillet + Greengram $)+50 \% \mathrm{RDN}+$ Azospirillum & 234.80 & 98.70 & 28.33 & 2.19 & 7.50 \\
\hline P.R. $($ Pearlmillet + Greengram $)+50 \% \mathrm{RDN}+$ Azotobacter & 239.90 & 101.00 & 27.83 & 2.41 & 7.67 \\
\hline $\begin{array}{l}\text { P.R. }(\text { Pearlmillet }+ \text { Greengram })+50 \% \text { RDN }+ \text { Azospirillum }+ \\
\text { Azotobacter }\end{array}$ & 250.03 & 103.33 & 28.97 & 2.96 & 8.10 \\
\hline U.R.( Pearlmillet Sole $)+50 \%$ RDN & 224.30 & 96.33 & 26.73 & 2.05 & 7.14 \\
\hline U.R.( Pearlmillet Sole ) $+100 \%$ RDN & 240.47 & 102.83 & 29.37 & 3.08 & 8.16 \\
\hline P.R.( Pearlmillet Sole $)+50 \%$ RDN & 224.20 & 97.60 & 26.53 & 2.14 & 6.52 \\
\hline P.R.( Pearlmillet Sole $)+100 \%$ RDN & 244.70 & 104.30 & 31.63 & 3.26 & 8.61 \\
\hline F Test & $\mathrm{S}$ & $\mathrm{S}$ & $\mathrm{S}$ & $\mathrm{S}$ & $\mathrm{S}$ \\
\hline $\mathrm{SEd} \pm$ & 7.20 & 0.98 & 1.28 & 0.42 & 0.66 \\
\hline $\mathrm{CD}(\mathrm{P}=0.05)$ & 14.81 & 2.02 & 2.64 & 0.87 & 1.35 \\
\hline
\end{tabular}


Table.2 Effect of different planting pattern and nitrogen management on growth, yield attributes and yield of greengram

\begin{tabular}{|c|c|c|c|c|c|}
\hline Treatment & $\begin{array}{c}\text { Plant } \\
\text { Height } \\
\text { (cm) }\end{array}$ & $\begin{array}{c}\text { Dry } \\
\text { Weight } \\
\text { (g) }\end{array}$ & $\begin{array}{c}\text { Number } \\
\text { of } \\
\text { grainspod }_{1}^{-}\end{array}$ & $\begin{array}{c}\text { Test } \\
\text { weight } \\
\text { ( gram) }\end{array}$ & $\begin{array}{l}\text { Grain Yield } \\
\quad\left(\text { tha }^{-1}\right)\end{array}$ \\
\hline U.R.( Pearlmillet + Greengram) + RDN & 62.26 & 9.41 & 11.55 & 32.88 & 0.84 \\
\hline U.R.( Pearlmillet + Greengram $)+50 \%$ RDN & 66.75 & 9.51 & 11.60 & 33.56 & 0.80 \\
\hline $\begin{array}{l}\text { U.R.( Pearlmillet }+ \text { Greengram })+50 \% \text { RDN+ } \\
\text { Azospirillum }\end{array}$ & 66.38 & 9.48 & 11.48 & 31.59 & 0.87 \\
\hline $\begin{array}{l}\text { U.R. ( Pearlmillet }+ \text { Greengram })+50 \% \text { RDN+ } \\
\text { Azotobacter }\end{array}$ & 66.75 & 10.02 & 11.78 & 32.12 & 0.81 \\
\hline $\begin{array}{l}\text { U.R. }(\text { Pearlmillet }+ \text { Greengram })+50 \% \text { RDN+ } \\
\text { Azospirillum }+ \text { Azotobacter }\end{array}$ & 69.79 & 9.49 & 11.42 & 33.67 & 0.86 \\
\hline P.R. ( Pearlmillet + Greengram $)+$ RDN & 70.36 & 10.05 & 11.90 & 33.64 & 0.94 \\
\hline P.R. $($ Pearlmillet + Greengram $)+50 \%$ RDN & 69.22 & 9.71 & 12.02 & 33.80 & 0.84 \\
\hline $\begin{array}{l}\text { P.R. ( Pearlmillet }+ \text { Greengram })+50 \% \text { RDN }+ \\
\text { Azospirillum }\end{array}$ & 68.04 & 9.75 & 12.64 & 34.30 & 0.92 \\
\hline $\begin{array}{l}\text { P.R. ( Pearlmillet }+ \text { Greengram })+50 \% \text { RDN }+ \\
\text { Azotobacter }\end{array}$ & 68.68 & 9.96 & 12.38 & 33.48 & 0.86 \\
\hline $\begin{array}{l}\text { P.R. }(\text { Pearlmillet }+ \text { Greengram })+50 \% \text { RDN }+ \\
\text { Azospirillum }+ \text { Azotobacter }\end{array}$ & 72.34 & 9.69 & 13.30 & 34.55 & 0.93 \\
\hline Greengram Sole & 74.71 & 10.24 & 13.52 & 34.82 & 1.13 \\
\hline F Test & $\mathrm{S}$ & $\mathrm{S}$ & $\mathrm{NS}$ & NS & NS \\
\hline $\mathrm{SEd} \pm$ & 1.16 & 0.15 & 0.67 & 1.42 & 0.08 \\
\hline $\mathrm{CD}(\mathrm{P}=0.05)$ & 2.41 & 0.33 & - & - & - \\
\hline
\end{tabular}


The highest spike length, grain yield and harvest index was due to better sunlight receptivity due to wider spacing between two paired rows, in addition to increased nitrogen availability by atmospheric nitrogen fixation in the root rhizosphere by seed inoculation with Azotobacter and Azospirillum culture. Rathore et al., (2006) reported that modified planting patterns (PR and PR+ Intercropping system) brought about a significant improvement in grain and stover yields of Pearlmillet over UR system of planting and Wani (2007) indicated that Pearl millet and Sorghum Crops inoculated with Azotobacter and Azospirillum which are grown as dryland crops showed $11-12 \%$ increased yields due to inoculations.

Growth, yield attributes and yield of greengram

Plant height and Plant dry weight of greengram showed a significant increase due to various treatments and maximum plant height $(74.71 \mathrm{~cm})$ and dry weight $(10.24 \mathrm{~g})$ was obtained in greengram sole as there is no competition. Number of grains pod ${ }^{-1}$, test weight and grain yield did not show significant difference among the treatments. The highest Number of grains pod ${ }^{-1}$ (13.52), test weight $(34.82 \mathrm{~g})$ and grain yield (1.13 $\mathrm{t} / \mathrm{ha}$ ) was recorded in greengram sole but in intercropping highest Number of grains pod ${ }^{-1}$, test weight and grain yield was recorded with 50\% RDN+ Azospirillum + Azotobacter (seed inoculation) in intercropping with paired row planting pattern. Due to better sunlight receptivity and wider spacing between two paired rows of pearlmillet in intercropping did not show significant effect on grain yield, test weight and number of grains/ pod of greengram (Table 2).

Based on the above findings, it can be concluded for obtaining higher profit from kharif Pearlmillet and greengram intercropping Pearlmillet should be sown in paired row and fertilized with $50 \mathrm{~kg} \mathrm{~N} / \mathrm{ha}$ along with seed inoculation with Azotobacter and Azospirillum, which significantly increased the plant height, dry weight, no. of tillers plant ${ }^{-1}$, test weight and grain yield of pearlmillet crop in addition to better yield of greengram. Although the finding is based on one year trial therefore it may be repeated to confirm the findings.

\section{References}

Alagawadi, A.R. \& Gaur, A.C. (1992). Inoculation of Azospirillum brasilense and phosphate- solubilizing bacteria on yield of sorghum (Sorghum bicolor L. Moench) in dry land. Trop. Agric. 69:347-350.

Han, X.M., Wang, R.Q., Liu, J., Wang, M.C., Zhou, J. and Guo, W.H. (2007).Effects of vegetation type on soil microbial community structure and catabolic diversity assessed by polyphasic methods in North China. Journal of Environmental Sciences, 19:1228-123

Meena,R.AndGautam, R.C.(2005). Effect Of Integrated Nutrient Management On Productivity, Nutrient Uptake And Moisture Use Functions Of Pearlmillet (Pennisetum glaucum).Indian Journal Of Agronomy 50(4):305-307.

Muraleedharan, H., Seshadri, S. and Perumal, K. (2010). Biofertiliser (Phosphobacteria), Shri Murrugapa Chettiar Research Centre.

Ram, K. and Meena,R.S.(2014).Evaluation of Pearlmillet and Mungbean intercropping systems in arid region of Rajasthan. Bangladesh J. Bot. 43(3): 367-370.

Ram, R., Chaudhary G.R., Jat,A.S. and Jat M.L.(2005). Effect of integrated weed management and intercropping systems on growth and yield of Pearlmillet (Pennisetum glaucum L.). Indian Journal of Agronomy 50 (3): 210-213. 
Rathore, V.S., Singh, P. and Guatam, R.C. (2006). Productivity and water-use efficiency of rainfed pearlmillet (Pennisetum glaucum) as influenced by planting patterns and integrated nutrient management. Indian Journal of Agronomy, 51(1):46-48

Sharma, B., Kumari, R., Singh, R.M., Nema, A.K. and Meena, S.(2015). Effect of planting patterns on yield and water use efficiency of Pearlmillet (Pennisetum glaucum) under rainfed condition of India. Environment and Ecology 33: 239-242.
Singh, R., Gupta,A.K., $\quad$ Ram,T., Choudhary,G.L. and Sheoran,A.C.(2013). Effect of Integrated nitrogen management on transplanted Pearlmillet (Pennisetum glaucum) under rained condition. Indian journal of Agronomy 58(1):81-85

Wani, S.P., Chandrapalaiah, S., Zambre, M.A. and Lee, K.K. (2007). Association between nitrogen-fixing bacteria and pearl millet plant, response, mechanisms and resistance. Plant Soil, 110:284-302.

\section{How to cite this article:}

Virpal Kaur and Rajesh Singh. 2017. Effect of Different Planting Pattern and Nitrogen Management in Pearlmillet (Pennisetum glaucum L.) + Greengram (Vigna radiata L.) Intercropping System. Int.J.Curr.Microbiol.App.Sci. 6(6): 1946-1951. doi: https://doi.org/10.20546/ijcmas.2017.606.227 